obituary

\section{G. Scatchard}

Georgr Scatchard was born in Oneonta, New York, on March 19, 1892, and died in Cambridge, Massachusetts, where he spent most of his life, on December 13, 1973. He received his $A B$ degree from Amherst in 1913 and his PhD from Columbia in 1917. His PhD degree was in organic chemistry, on the synthesis and properties of quinazolines, but his interest shifted early to physical chemistry, and it is as a phrisical chemist, or, more precisely, as a thermodynamicist, that he established his reputation. $\mathrm{He}$ was Professor of Physical Chemistry at MIT for most of his career.

George Scatchard loved thermodynamics, its pure simplicity of expression, its certainty, its complete freedom from questionable assumptions. The vaguely understood effects of intermolecular interactions are always rigorously included in his equations as activity coefficients and their derivatives. Much of his theoretical work was concerned with the extraction of these non-ideal parameters from experimental data, with their interpretation, and with extrapolation methods that would eliminate them and permit exact determination of the simpler parameters, such as standard electrode potential and molecular weight, that enter into the definition of ideal thermodynamic behaviour. In the laboratory, George Scatchard dedicated himself to valiant efforts to match experimental precision to the precision of the equations he used for analysis. A characteristic of all his work, painfully discovered by many less patient experimenters who have sought to use his methods for analysis of their own data, is his ingenuity in devising plotting procedures that amplify experimental error and reveal at a glance the uncertainty of an extrapolation or in the drawing of a tangent.

George Scatchard was a severe critic. $\mathrm{He}$ did not necessarily expect others to match his own precision of thought or experiment, but he expected them to try their best. When he detected gross confusion or misconceptions, and especially when they masqueraded behind a facade of glib showmanship, he could be merciless. He will not be forgotten by anyone who presented scminars at the Harvard-MIT Physical Chemistry Colloquium when he was present. There was a perpetual frown on his face, deepening in intensity at each point where the speaker was glossing over theoretical or experimental difficultics. At the end of the seminar there was relief when he asked an innocuous question, and (depending on the personality of the speaker) either anger or a silent resolve never to err again when he rose to expose a fallacy. There are undoubtedly some who remember George Scatchard with less than affection as the result of such an encounter, but there are many more who are grateful for his cxample and for the effect it had of raising their own standards of what is and what is not a valid piece of scientific research. As might be expected, George Seatchard's scientific papers often had the purpose of defining parameters and establishing methodology.

From $1930-40$ he was mostly concerned with the thermodynamies of soltttions, and especially of aqueous solutions of electrolytes beyond the range of applicability of limiting laws. During this period he developed the isopiestic method for evaluating osmotic and activity coefficient, and wrote definitive papers on the use of clectromotive force and freezing point depression. He also wrote purely theorctical papers including a pioneering paper with John G. Kirkwood, during tenure of a Guggenheim Fellowship in Leipzig, on the electrostatic interactions of zwitterions.

During the Second World War, he divided his time between the Manhatten project of the AEC and the blood plasma fractionation project at. Harvard directed by F. J. Cohn, who had been a fellow undergraduate at Amherst and was a life-long friend. The latter work led to a general interest in proteins and to his classic papers in 1946 on the state of cquilibrium across a semipermeable. membrane. These papers were written to provide $a$ sound foundation for osmotic pressure measurements of protein solutions at finite concentrations, but of course apply quite generally to all thermodynamic properties of multicomponent macromolecular solutions. Explicit extension to sedimentation equilibrium was made by Scatchard himself in 1954 . The same basic theory provided the foundation for Scatchard's experimental work on the binding of ionic ligands to proteins and their interpretation in terms of syecific binding sites and association constants, as well as for several papers on transport across semipermeable membranes.

There are very few scientists whose work one can legitimately compare with that of the handful of all-time great in- tellects. Such a comparison can be made, without appearing presumptious, between George Scatchard and I. Willard Gibbs. Nor is it derogatory to George Scatchard, in making this comparison, so say that Gibbs led the way and Scatchard followed for Scatchard himself said so. Few have the mental discipline that is required to go beyond a comprehension of what Gibbs accomplished, to an understanding of how he did it, to a sufficient insight into his thought process to be able to emulate it and to apply it to new and complex situations and George Scatchard was unique in his generation in his ability to do so. Without him many of the fruits of Gibbs' work would not have been gathered so soon.

\section{A Coulson}

Just over a century ago, T. H. Huxley wrote a paper in which he described the liberally educated man as one "who has been so trained in his routh that his body is the ready servant of his will and does with ease and pleasure all the work that, as a mechanism, it is capable of: where intellect is a clear cold logic engine with all its parts of equal strength and in smooth working order ... whose mind is stored with the great and fundamental truths of $\mathrm{Na}$ ture ... and who, no stunted ascetic is full of life and fire, but whose passions are trained to come to heel by a vigorous will, the servant of a tender conscience; who has learned to love all beauty, whether of Nature or of art, to hate all vileness and to respect others as himself". It is ironic that an atheist should have so adequately encompassed the life and style of Charles Coulson that, provided 'Christian' is substituted for 'tender' no better words could be found for his cpitaph. This remarkable man was born in 1910 and died in Oxford on January 6, 1974. steadfast to the end in his adherenee to his principles and beliefs and in his sense of duty to others so that his last concerns were not for himself but for those at home and in his department who were, in diverse ways, dependent on him.

He entered Trinity College, Cambridge, from his local Grammar School as an open scholar and duly and predietably collected his first in the Tripos examinations. His first paper in 1931 was essentially an attempted criticism of one of the redoubtable Harold Jeffreys' conclusions and its writing epi- 
tomised his unfettered pursuit of truth even if it led him into conflict with higher authority. In due course he was elected a Research Fellow of Trinity sharing this distinction with two physicists also with Methodist connections, the late I. H. Gray FRS and D. E. Lea. Their scientific interests converged in the then embryonic study of the action of ionising radiation on living systems. Lca and Gray went on to make most distinguished contributions to this field, but Coulson's was not particularly outstanding and he turned to the newly emerged subject of theoretical chemistry, then broadly defined as the application of Wave Mechanies to molecular structure and bonding, which occupied him for the last 37 years of his life successively as lecturer in University College Dundee, ICI Fellow in the Physical Chemistry Laboratory at Oxford, Professor of Theoretical Physics at King's College London, Rouse Ball Professor of Mathematics at Oxford (for about 20 years) and finally as the foundation Professor of Theoretical Chemistry at Oxford.

A combination of enthusiasm, great industry, fluency and an uncanny judge- ment of when to approximate made him a most prolific author (three books and over 300 papers). He touched on many chemical problems such as aromaticity, conjugation and hyperconjugation, charge distribution, shapes of molecules in ground and excited states. If his role initially was often to provide post hoc quantum-chemical justifications for many qualitative and semi-quantitative relations empirically perceived by chemists, he correctly foresaw that, once the computational obstacles had been overcome, the latent predictive powers of quantum chemistry would be realised and that it might outstrip instruments in quantitative precision.

Coulson will perhaps be remembered more as an unusually gifted teacher than a great researcher. He liked young people and they liked him-in their patois he 'related'. He had great sympathy for the intellectual difficulties of beginners and spared no pains in helping them. He loved lecturing and was a brilliant expositor, leaving his audience eager for more and confident that he could help them to an understanding which would enable them to select and solve prob- lems. His summer schools in theoretical chemistry were world famous and a powerful influence in the dissemination of ideas and the development of the subject. They augmented the already strong attraction of Coulson's department for overseas visitors who often seemed to predominate in his research group.

Obituaries in Nature emphasise scientific achievement but it would be unjust to Coulson's memory not to recall that he was a decply concerned Christian. This was manifested not only in his lay. preaching to small congregations in insignificant Methodist. Chapels or his public lectures to sophisticated audiences as in his Gifford lectures, but also in his willingness to play very active parts in organisations-such as a VicePresident of the Methodist Conference or as a working Chairman of Oxfam.

Honours were poured on Coulson but are not enumerated here for he would have preferred to be remembered simply as a practical idealist anxious to add to the sum of human happiness and understanding by advancing knowledge and by teaching and helping others, all of which he achieved abundantly.

\section{Announcements}

\section{Appointments}

J. Bardeen, H. B. G. Casimir, L. E. F. Neel, Sir Rudolf Peierls and Sir Alan Wilson have been elected Honorary Fellows of the Institute of Physics.

Sir Michael Perrin has been appointed a Trustee of the British Museum (Natural History).

\section{Awards}

The Council of the Institute of Physics has awarded the Guthrie Medal and Prize to R. L. Mossbäuer of the Institut Max von Laue-Paul Langevin; the Rutherford Medal and Prize to A. E. Litherland of the University of Toronto; the Glazebrook Medal and Prize to B. J. Mason of the Meteorological Office; the Charles Vernon Boys Prize to P. G. H. Sanders of the University of Oxford; the Maxwell Medal and Prize to S. F. Edwards of the University of Cambridge and the Max Born Medal and Prize to W. Greiner of the University of Frankfurt.

The Councils of the French Physical Society and the Institute of Physics have awarded the $\mathbf{1 9 7 4}$ Holweck Medals and Prizes to A. Hewish of the University of Cambridge and $\mathbf{P}$. Nozieres of the Institut Max von Laue-Paul Langevin.
The Royal Society has awarded the first Herschel Medal to P. Wild of the CSIRO Division of Radiophysies.

\section{Erratum}

IN Fig. 1 of the article "Nitrosocarbaryl as a potent mutagen of environmenal significance" by R. Elespuru W. Lijinsky and Jane K. Setlow (Nature, 247, 386; 1974), the vertical axis should have bcen labelled mutants/survivor. On line 17 of the figure legend $0.01 \mathrm{M}$ NC should read $0.01 \mathrm{mM}$ NC.

\section{Corrigendum}

In the article, "Mechanism of denaturation of haemoglobin by alkali" by M. F. Perutz (Nature, 247, 351; 1974) on page 343, paragraph 3 , lines 9 and 10 of the section 'Probable mechanism' should read "Alkali denaturation of human oxyhaemoglobin has a negative entropy of activation ..." and the first author of ref. 29 was misspelt and should be Air, G. M.

\section{International meetings}

April 8-10, 18th Annual Meeting of the Ecological Genetics Group (G. E. Marks, The John Innes Institute, Norwich, UK)

April 8-10, Course on Quantitative Microscopy for Materials Scientists (The Administrator, Royal Microscopical Society, Clarendon House, Cornmarket Strect, Oxford OX1 3HA)
April 8-10, 8th Thin Films Conference (The Mectings Officer, The Institute of Physics, 47, Belgrave Sqquare, London SW1X 80X)

April 8-11, The Engineering Uses of Coherent Optics (Mr F. R. Robertson, Department of Mechanics of Materials, University of Strathelyde, Glasgow)

$\Lambda$ pril 8-12, International Symposium on Wound Healing (Secretariat International Srmposium on Wound Healing, c/o Holland Organising Centre, 16, Lange Voorhout, The Hague, The Netherlands)

April 9, Society for Drug Research Symposium on Essential Hypertension (Dr A. B. Simmonds, Chelsea College, Manresa Road, London SW3)

April 9-10, Microstructure and Physical Properties of Non-metallic Materials (Dr D. Dew-Hughes, Department of Physies, University of Lancaster, Lancaster)

April 9-11, Gels and the Gelling Process (The Faraday Division, The Chemical Society, Burlington Housc, London W1V OBN)

April 10, Applications of Remote Sensing-Data Processing and Analysis (R. W. Laing. Electro-Optics Division, Hawker Siddley Drnamies Ltd., Manor Road, Hatfield, Hertfordshire AL10 9LL)

April 15-16, 11th Annual Rocky Mountain Bioengineering Symposium (Clifford D. Ferris, The University of Wyoming, College of Fnginesring, Laramie, Wyoming 82070) 